\title{
New County Record for the Veiled Chameleon (Chamaeleo calyptratus Duméril and Bibron 1851), in Broward County, Florida, With Notes on Intentional Introductions of Chameleons in Southern Florida
}

\author{
Jake R. Edwards ${ }^{1}$, Michael R. Rochford ${ }^{2}$, Frank J. Mazzotti ${ }^{2}$, and Kenneth L. Krysko ${ }^{3}$ \\ ${ }^{1}$ Florida Fish and Wildlife Conservation Commission, 3205 College Avenue, Fort Lauderdale, Florida 33314, USA (jake.edwards@myfwc.com) \\ ${ }^{2}$ University of Florida, Fort Lauderdale Research and Education Center, 3205 College Avenue, Fort Lauderdale, Florida 33314, USA \\ (MRR: miker@ufl.edu, FJM: fjma@ufl.edu) \\ ${ }^{3}$ Division of Herpetology, Florida Museum of Natural History, University of Florida, 1659 Museum Road, Gainesville, Florida 32611, USA (kenneyk@ufl.edu)
}

$\mathrm{T}_{\mathrm{r} \text { hen }}^{\mathrm{h}}$ he Veiled Chameleon (Chamaeleo calyptratus) is an arboreal lizard native to Saudi Arabia and Yemen, where it is found on high plateaus to elevations of $2,800 \mathrm{~m}$ and in foothills, forests, low-elevation maize fields, and inland river valleys (Fritz and Schütte 1987, Meerman and Boomsma 1987, Zari 1993, Showler 1995, Schmidt 2001). This species has been introduced via the pet trade to Hawaii (Kraus and Duvall 2004) and Florida (Krysko and Enge 2004), USA. In Florida, it has been established since at least 2002 (Krysko and Enge 2004) and evidence of additional independent introductions exist from Alachua, Collier, Hendry, Lee, and Miami-Dade counties (Krysko et al. 2011, Gillette and Krysko 2012). Herein, we document another introduction of C. calyptratus in Broward County, Florida.

On 30 December 2013, the University of Florida received an anonymous tip about a possible population of Chamaeleo calyptratus on state-owned lands in Broward County. On 1 January 2014 between 1900-2100 h, JRE and MRR conducted a nighttime search around a Florida Highway Patrol station and area right-of-way. At approximately $1930 \mathrm{~h}$, we observed an adult female C. calyptratus (photographic voucher UF-Herpetology 172296) sleeping on a Brazilian Pepper Tree (Schinus terebinthifolius) about $2.5 \mathrm{~m}$ above the ground $\left(26.11969^{\circ} \mathrm{N},-80.33859^{\circ} \mathrm{W}\right.$, Datum WGS84, $5 \mathrm{~m}$ elevation). At approximately $2000 \mathrm{~h}$, we observed flashlights in a nearby area. Upon contact, two people revealed themselves to be commercial chameleon collectors who had two C. calyptratus in their possession. The collectors told us the chameleons were collected from the same site that evening. At $2025 \mathrm{~h}$, we observed an adult male C. calyptratus (UF-Herpetology
172297) sleeping on a S. terebinthifolius about $3 \mathrm{~m}$ above the ground $\left(26.12038^{\circ} \mathrm{N},-80.33814^{\circ} \mathrm{W}\right)$. Digital images of the chameleons were sent to Laurence L. Connor (Florida Fish and Wildlife Conservation Commission) who confirmed our identifications. Vouchered specimens are crucial in documenting introductions (Krysko et al. 2011) and these known vouchers represent the first two C. calyptratus from Broward County.

On 2 January 2014, MRR and Michelle J. Curtis (University of Florida) conducted a second survey of the area. A C. calyptratus of unknown sex was observed at $2106 \mathrm{~h}$, perched on a $S$. terebinthifolius about $3 \mathrm{~m}$ above the ground $\left(26.11993^{\circ} \mathrm{N},-80.33974^{\circ} \mathrm{W}\right)$. Another C. calyptratus of unknown sex was observed perched in another $S$. terebinthifolius about $4 \mathrm{~m}$ above the ground at $2110 \mathrm{~h}\left(26.11972^{\circ} \mathrm{N}\right.$, $\left.-80.33869^{\circ} \mathrm{W}\right)$. Both chameleons were behind a fence, preventing collection or satisfactory photographs.

The release of nonnative wildlife is illegal (Rule 68-5 F.A.C) and Florida law considers release of nonnative wildlife to be a misdemeanor (Florida Statute $\$ 379.231$ ). Despite this, multiple chameleon populations have been discovered throughout the state (Figs. $1 \& 2$ ), but primarily in southern Florida. Rumors abound that animals were intentionally released by individuals interested in harvesting them from the wild for future sale in the pet trade. On several occasions, JRE and MRR observed collectors trespassing on posted private lands to obtain chameleons. For example, Oustalet's Chameleons (Furcifer oustaleti) in Miami-Dade County, Florida, were first observed to be introduced into a private property (Gillette et al. 2010) and subsequently have 
spread to county-owned land (UF-Herpetology 163066, $163067,165705,170786)$. Further discoveries of F. oustaleti (UF-Herpetology 166502, 166565, 166123) found up to $11 \mathrm{~km}$ from the originally reported population are suggestive of subsequent translocations. More recently Panther Chameleons (Furcifer pardalis) were discovered in Broward
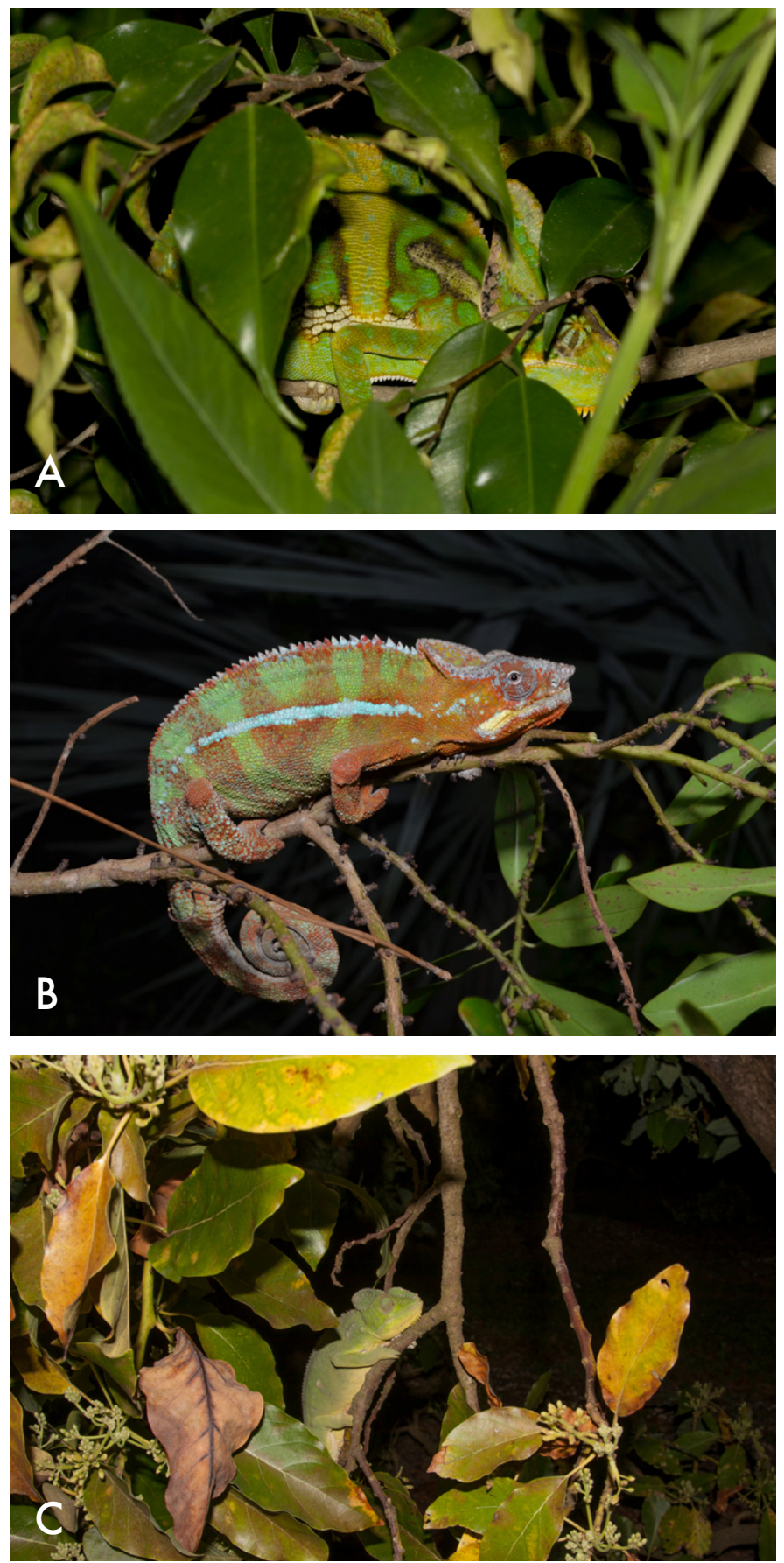

Fig. 1. Chameleons introduced to Florida: A. Veiled Chameleon (Chamaeleo calyptratus) (UF-Herpetology 166817), Miami-Dade County, Florida, photograph by Christopher Gillette; B. Panther Chameleon (Furcifer pardalis) (UF-Herpetology 170801), Broward County, Florida, photograph by Michael R. Rochford; C. Oustalet's Chameleon (Furcifer oustaleti) (UF-Herpetology 165207, Miami-Dade County, Florida, photograph by Kenneth L. Krysko.

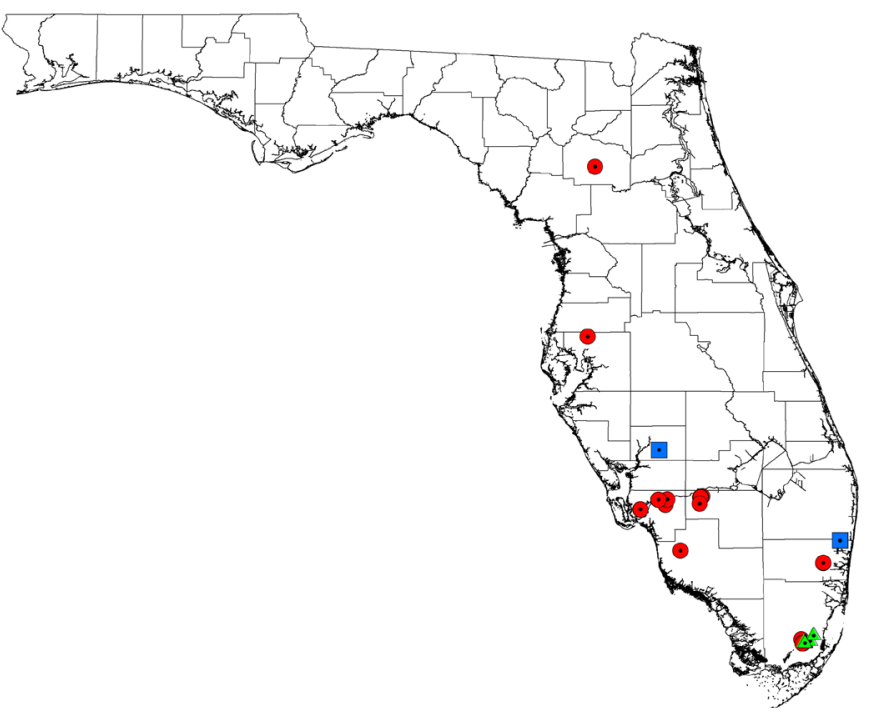

Fig. 2. Verified records of three species of Chameleons in Florida, USA. Red circles: Chamaeleo calyptratus; green triangles: Furcifer oustaleti; blue squares: F. pardalis. Records in Alachua, Collier, De Soto, and Hillsborough counties represent single individuals.

County (Rochford et al. 2013). Throughout Florida, $C$. calyptratus now occurs on both private property and stateowned rights-of-way (Krysko et al. 2011, Gillette and Krysko 2012). With this new introduction, we document ongoing intentional introductions of chameleons throughout southern Florida.

\section{Acknowledgments}

We thank Michelle Curtis for assistance in the field. Jennifer Ketterlin Eckles, Liz Barraco, Marsha Wheatley, and Kristen Sommers commented on this note. Laurence Connor assisted in data coordination and specimen identification. Christopher Gillette provided a photograph for this note. We also thank the citizen who reported this introduction; that report testifies to the value of stakeholder engagement and communication.

\section{Literature Cited}

Gillette, C.R. and K.L. Krysko. 2012. New county record for the Veiled Chameleon, Chamaeleo calyptratus Duméril and Bibron 1851 (Sauria: Chamaeleonidae), in Florida. Reptiles \& Amphibians 19:130-131.

Gillette, C.R., K.L. Krysko, J.A. Wasilewski, G.N. Kieckhefer III, E.F. Metzger III, M.R. Rochford, D. Cueva, and D.C. Smith. 2010. Oustalet's Chameleon, Furcifer oustaleti (Mocquard 1894) (Chamaeleonidae), a non-indigenous species newly established in Florida. Reptiles \& Amphibians 17:248-249.

Fritz, J.P. and F. Schütte. 1987. Zur Biologie jemenitischer Chamaeleo calyptratus Duméril \& Duméril, 1851 mit einigen Anmerkungen zum systematischen Status (Sauria: Chamaeleonidae). Salamandra 23:17-25.

Kraus, F. 2009. Alien Reptiles and Amphibians: A Scientific Compendium and Analysis. Invading Nature: Springer Series in Invasion Biology 4. Springer, Dordrecht, The Netherlands.

Kraus, F. and F. Duvall. 2004. New records of alien reptiles and amphibians in Hawaii. Bishop Museum Occasional Papers 79:62-64.

Krysko, K.L., K.M. Enge, and F.W. King. 2004. The Veiled Chameleon, Chamaeleo calyptratus: A new exotic species in Florida. Florida Scientist 67:249-253.

Krysko, K.L., K.M. Enge, and P.E. Moler. 2011. Atlas of Amphibians and Reptiles in Florida. Final Report, Project Agreement 08013, Florida Fish and Wildlife Conservation Commission, Tallahassee. 
Meerman, J. and T. Boomsma. 1987. Beobachtungen an Chamaeleo calyptratus calyptratus Duméril \& Duméril, 1851 in der Arabischen Republik Jemen (Sauria: Chamaeleonidae). Salamandra 23:10-16.

Rochford, M.R., J.R. Edwards, P.L. Howell, J. Ketterlin Eckles, L.A. Barraco, L.L Connor, M.J. Curtis, K.L.Krysko, and F.J Mazzotti. 2013. The Panther Chameleon, Furcifer pardalis (Cuvier 1829) (Chamaeleonidae), another introduced chameleon species in Florida. Reptiles \& Amphibians 20:205-207.
Schmidt, W. 2001. Chamaeleo calyptratus. The Yemen Chameleon. Natur und TierVerlag GmbH, Berlin, Germany.

Showler, D. 1995. Reptile observations in Yemen, March-May 1993. The Herpetological Bulletin 53:13-23.

Zari, T.A. 1993. Effects of body mass and temperature on standard metabolic rate of the Desert Chameleon Chamaeleo calyptratus. Journal of Arid Environments 24:75-80. 